\title{
Serotonin 2A Receptors Differentially Contribute to Abuse-Related Effects of Cocaine and Cocaine-Induced Nigrostriatal and Mesolimbic Dopamine Overflow in Nonhuman Primates
}

\author{
Kevin S. Murnane, ${ }^{1}$ Jake Winschel, ${ }^{1}$ Karl T. Schmidt, ${ }^{1}$ LaShaya M. Stewart, ${ }^{1}$ Samuel J. Rose, ${ }^{1}$ Kejun Cheng, ${ }^{3}$ \\ Kenner C. Rice, ${ }^{3}$ and Leonard L. Howell ${ }^{1,2}$ \\ ${ }^{1}$ Division of Neuropharmacology and Neurologic Diseases, Yerkes National Primate Research Center, and ${ }^{2}$ Department of Psychiatry and Behavioral \\ Sciences, Emory University, Atlanta, Georgia 30322, and ${ }^{3}$ Chemical Biology Research Branch, National Institute on Drug Abuse and National Institute on \\ Alcohol Abuse and Alcoholism, National Institutes of Health, Bethesda, Maryland 20892
}

Two of the most commonly used procedures to study the abuse-related effects of drugs in laboratory animals are intravenous drug self-administration and reinstatement of extinguished behavior previously maintained by drug delivery. Intravenous selfadministration is widely accepted to model ongoing drug-taking behavior, whereas reinstatement procedures are accepted to model relapse to drug taking following abstinence. Previous studies indicate that 5 - $\mathrm{HT}_{2 \mathrm{~A}}$ receptor antagonists attenuate the reinstatement of cocaine-maintained behavior but not cocaine self-administration in rodents. Although the abuse-related effects of cocaine have been closely linked to brain dopamine systems, no previous study has determined whether this dissociation is related to differential regulation of dopamine neurotransmission. To elucidate the neuropharmacological and neuroanatomical mechanisms underlying this phenomenon, we evaluated the effects of the selective 5- $\mathrm{HT}_{2 \mathrm{~A}}$ receptor antagonist $\mathrm{M} 100907$ on intravenous cocaine self-administration and drugand cue-primed reinstatement in rhesus macaques (Macaca mulatta). In separate subjects, we evaluated the role of 5-HT $2 \mathrm{~A}$ receptors in cocaine-induced dopamine overflow in the nucleus accumbens $(n=4)$ and the caudate nucleus $(n=5)$ using in vivo microdialysis. Consistent with previous studies, M100907 (0.3 mg/kg, i.m.) significantly attenuated drug- and cue-induced reinstatement but had no significant effects on cocaine self-administration across a range of maintenance doses. Importantly, M100907 (0.3 mg/kg, i.m.) attenuated cocaine-induced $(1.0 \mathrm{mg} / \mathrm{kg}$, i.v. $)$ dopamine overflow in the caudate nucleus but not in the nucleus accumbens. These data suggest that important abuse-related effects of cocaine are mediated by distinct striatal dopamine projection pathways.

\section{Introduction}

Cocaine abuse is a major public-health concern (Johnston et al., 2011). Clarifying the neuropharmacological and neuroanatomical systems that mediate the abuse-related effects of cocaine is likely to support the rational development of new medications to treat cocaine abuse. Two procedures commonly used to study abuse-related effects in laboratory animals are intravenous cocaine self-administration and reinstatement of extinguished be-

\footnotetext{
Received April 4, 2013; revised June 28, 2013; accepted July 8, 2013.

Author contributions: K.S.M. and L.L.H. designed research; K.S.M., J.W., K.T.S., L.M.S., S.J.R., K.C., and K.C.R. performed research; K.S.M. and J.W. analyzed data; K.S.M., J.W., K.T.S., L.M.S., S.J.R., K.C., K.C.R., and L.L.H. wrote the paper.

These studies were supported by United States Public Health Service Grants DA010344, DA012514, and RR00165, and is currently supported by the National Institutes of Health Office of Research Infrastructure Programs Grant ODP510D11132. A portion of this work was supported by the Intramural Research Programs of the National Institute on Drug Abuse and the National Institute on Alcohol Abuse and Alcoholism. We thank both Juliet Brown and Lisa Neidert for their expert technical assistance.

The authors declare no potential financial conflicts of interest.

Correspondence should be addressed to Leonard L. Howell, Yerkes National Primate Research Center, Emory University, 954 Gatewood Road, Atlanta, GA 30322. E-mail: Ihowell@emory.edu.

DOI:10.1523/JNEUROSCI.1437-13.2013

Copyright $\odot 2013$ the authors $\quad 0270-6474 / 13 / 3313367-08 \$ 15.00 / 0$
}

havior previously maintained by drug delivery. Intravenous selfadministration is widely accepted to model ongoing drug-taking behavior (O'Brien and Gardner, 2005), whereas reinstatement procedures are accepted to model relapse once abstinence has been achieved (Stewart and de Wit, 1987). Importantly, a critical role for dopamine neurotransmitter systems in these abuserelated behaviors has become accepted (Howell and Murnane, 2008).

Despite acceptance of dopamine systems as central to cocaine abuse, few studies have examined how different dopaminergic projections contribute to specific abuse-related effects of cocaine, particularly in nonhuman primates. Two major pathways of the dopamine system are the nigrostriatal and mesolimbic systems. The mesolimbic pathway is believed to be involved in reinforced or motivated behavior, whereas the nigrostriatal pathway is believed to be involved in habitual and associative behavior and the instigation, coordination, and termination of motor movements (Haber et al., 2006; Haber and Knutson, 2010). Furthermore, elaborate neuroimaging work in nonhuman primates and rodents has shown that the nucleus accumbens (NAc), which is the major output region of the mesolimbic pathway, is activated by 
cocaine self-administration in individuals with a limited history of consuming cocaine. In contrast, both the NAc and caudate nucleus, which is one of the two major output regions of the nigrostriatal pathway, are activated following more extensive histories of cocaine consumption (Ito et al., 2002; Porrino et al., 2007; Belin and Everitt, 2008), suggesting that understanding these systems will elucidate the transition from recreation to compulsive cocaine abuse. Although it is therefore reasonable to predict that the mesolimbic pathway is critically involved in cocaine self-administration and the nigrostriatal pathway is critically involved in reinstatement of extinguished behavior previously maintained by cocaine delivery, we do not fully understand the differential contributions of the mesolimbic and nigrostriatal dopaminergic pathways to cocaine selfadministration and reinstatement, especially in nonhuman primates.

Previous work in rodents has shown that antagonizing $5-\mathrm{HT}_{2 \mathrm{~A}}$ receptors attenuates reinstatement but not cocaine selfadministration (Fletcher et al., 2002; Nic Dhonnchadha et al., 2009). In this study, to elucidate the neuropharmacological and neuroanatomical basis of this dissociation, we determined whether $5-\mathrm{HT}_{2 \mathrm{~A}}$ receptor antagonism attenuates cocaine selfadministration and reinstatement in nonhuman primates, and whether it differentially affects dopamine overflow through the mesolimbic and nigrostriatal pathways. The differential role of $5-\mathrm{HT}_{2 \mathrm{~A}}$ receptors in cocaine self-administration and reinstatement should generalize from rodents to primates because a previous study reported that antagonizing $5-\mathrm{HT}_{2 \mathrm{~A}}$ receptors does not attenuate cocaine self-administration in primates (Fantegrossi et al., 2002), and we have recently found high $5-\mathrm{HT}_{2 \mathrm{~A}}$ receptor availability in the prefrontal cortex (PFC) of primates (Sawyer et al., 2012), an area putatively critical to reinstatement but not self-administration (Kalivas, 2009). Accordingly, antagonism of this receptor may be an excellent means of elucidating the neuropharmacology and neuroanatomy of specific abuserelated effects of cocaine.

\section{Materials and Methods}

Subjects. All behavioral studies were conducted in a group of three adult female rhesus monkeys (RRg4, RLl4, RMv3; Macaca mulatta) that weighed 7-9.5 kg. Four adult female rhesus monkeys (RJt7, RLt7, RNb7, and $\mathrm{RHp} 8$ ) weighing 7-9.5 kg served as the subjects of the in vivo microdialysis experiments targeting NAc, which is the striatal region targeted by the mesolimbic dopamine projections arising from cell bodies in the ventral tegmental area (VTA). Four adult female rhesus monkeys (RKa10, RGg9, RZq8, and RDn8) weighing 7-9.5 kg and one adult male rhesus monkey (RKn8) weighing $\sim 12 \mathrm{~kg}$ served as the subjects of the in vivo microdialysis experiments targeting the caudate nucleus, which is the striatal region targeted by the nigrostriatal dopamine projections arising from cell bodies in the substantia nigra (SN). All subjects were fed monkey-diet chow (PMI Nutrition International), fresh fruits, and vegetables daily. They were also supplied with nutritional and psychological enrichment. Ambient conditions within the colony were maintained at a temperature of $22 \pm 2^{\circ} \mathrm{C}$ and at $45-50 \%$ humidity. The room lighting was set to a $12 \mathrm{~h}$ light/dark cycle, with the light period from 7:00 A.M. to 7:00 P.M. Water was continuously available, and no subject underwent food restriction procedures. All subjects had a pharmacology history of exposure to cocaine and other stimulant-type drugs of abuse. All protocols and animal care and handling strictly followed the National Institutes of Health Guide for the Care and Use of Laboratory Animals and the recommendations of the American Association for Accreditation of Laboratory Animal Care, and were approved by the Emory University Animal Care and Use Committee.

Surgery. Before this study, a major vein (femoral or jugular) in all subjects was implanted with a chronic indwelling catheter attached to a subcutaneous vascular access port using aseptic surgical techniques, as previously described (Wilcox et al., 2002). To maintain patency, the catheters were flushed with heparinized saline $(100 \mathrm{U} / \mathrm{ml})$ regularly in the subjects of the microdialysis experiments and at the end of each operant session in the subjects of the behavioral experiments. The subjects of the microdialysis experiments were also implanted with bilateral CMA/11 guide cannulae (CMA Microdialysis) that were stereotaxically targeted for the striatum, as previously described (Murnane et al., 2010). To target the area of the head of the caudate directly over the NAc, the probes were advanced $23 \mathrm{~mm}$ anterior to the interaural midpoint in each female subject and $27 \mathrm{~mm}$ anterior to the interaural midpoint in the male subject. The probes were placed bilaterally at $4 \mathrm{~mm}$ off of the midline in all subjects. During each surgery, subjects were prophylactically administered an antibiotic (Rocephin), an analgesic (buprenorphine), and a nonsteroidal anti-inflammatory agent (Banamine) to minimize any discomfort from the surgery.

Drugs. Cocaine hydrochloride (National Institute on Drug Abuse) was dissolved in physiological saline. M100907 was synthesized at the Chemical Biology Research Branch, National Institute on Drug Abuse and National Institute on Alcohol Abuse and Alcoholism at the National Institutes of Health, and was provided as a generous gift from K.C.R. M100907 was dissolved in sterile water and 0.1N hydrochloric acid. In all experiments, we examined the effects of M100907 at a dose of $0.3 \mathrm{mg} / \mathrm{kg}$ administered intramuscularly. We used this dose because we have previously shown that it attenuates secretion of prolactin (Murnane et al., 2012) and suppression of operant responding (Fantegrossi et al., 2009) elicited by 3,4-methylenedioxymethamphetamine (MDMA) in nonhuman primates. Moreover, we have shown that this dose of M100907 significantly attenuates stimulant-typical behavioral effects and increased dopamine overflow in the caudate elicited by amphetamine in rhesus macaques (Murnane et al., 2013). For all studies, we used a $1 \mathrm{~h}$ pretreatment time between intramuscular administration of M100907 and intravenous cocaine administration because we have determined that this pretreatment time provides better suppression of the behavioral effects of stimulants than shorter times (Murnane et al., 2013). The doses of each drug were calculated and are expressed as the salt form.

Cocaine self-administration. The subjects of the behavioral experiments were initially trained to self-administer cocaine under a threecomponent fixed-ratio (FR) 20 schedule of reinforcement. As previous studies have shown that $5-\mathrm{HT}_{2 \mathrm{~A}}$ receptor antagonism does not alter cocaine self-administration (Fantegrossi et al., 2002; Fletcher et al., 2002; Nic Dhonnchadha et al., 2009), this schedule was designed to elicit high and consistent rates of behavior, with the expectation that this would maximize our opportunity to observe any attenuation of cocaine selfadministration by M100907. Self-administration sessions were conducted in an operant test chamber with a controlled environment, as described previously (Wilcox et al., 2005). These sessions lasted $80 \mathrm{~min}$ and were typically conducted $5 \mathrm{~d}$ per week. The timing and coordination of experimental events were controlled by Med-PC IV software (Med Associates Inc.). Each session began with a 5 min start delay, after which the initiation of the schedule contingencies, including the availability of cocaine, was signaled by the illumination of a white light on the response panel. During the active period of each component, completion of the response requirement resulted in the delivery of a $0.5 \mathrm{ml}$, i.v., bolus of cocaine over $3 \mathrm{~s}$. During each cocaine delivery, the white session light was extinguished and a red light designed to function as a conditioned reinforcer was illuminated on the response panel. Following each cocaine delivery, a 2 min timeout period was initiated wherein all lights were extinguished and responding had no programmed consequences. Each component lasted $15 \mathrm{~min}$, including both the active and timeout periods, allowing the subjects to earn a maximum of eight infusions per component. Each of the three components was separated by an intercomponent interval of $15 \mathrm{~min}$ wherein all lights were extinguished and responding had no programmed consequences. The unit dose of cocaine available between sessions was altered by changing the dissolved concentration of the drug. The response rate was calculated as the total number of responses emitted during the active period divided by the active time throughout the entire session. We operationally defined stable selfadministration behavior as response rates that varied by $<20 \%$ over $3 \mathrm{~d}$. 
Once responding stabilized at a given unit dose of cocaine, M100907 was administered intramuscularly $1 \mathrm{~h}$ before the initiation of the schedule contingencies, including the availability of cocaine. As some drugs that target serotonin systems are more effective when given over several days (Davidson et al., 2004), we determined whether subchronic administration of M100907 over 3 contiguous days (Wednesday through Friday) engendered more effective suppression of cocaine selfadministration. The effects of M100907 were determined across a range of cocaine doses $(0.01,0.03$, and $0.1 \mathrm{mg} / \mathrm{kg} /$ infusion $)$. Following testing of the effects of M100907 on cocaine self-administration at a given unit dose, the unit dose of cocaine was changed and responding was allowed to stabilize. All subjects were maintained on the same unit dose of cocaine during a round of testing. The unit doses of cocaine were examined in pseudo-randomized order.

Reinstatement. For the reinstatement experiments, behavior was maintained by the unit dose of cocaine that engendered the highest response rates $(0.03 \mathrm{mg} / \mathrm{kg} / \mathrm{infusion})$. Each round of reinstatement testing consisted of extinguishing the behavior, a reinstatement test day, and subsequently re-establishing stable cocaine self-administration. Behavior was extinguished by substituting the drug-vehicle saline for cocaine, and was operationally defined as a rate of responding over two sequential sessions that was $<20 \%$ of the $3 \mathrm{~d}$ mean rate of responding during the maintenance of cocaine self-administration. During the extinction sessions, the conditioned reinforcer was never illuminated. Otherwise, the extinction sessions were identical to the maintenance sessions. The reinstatement test day consisted of an experimenter-administered prime of cocaine given through the vascular access port immediately before the initiation of the $5 \mathrm{~min}$ start delay that immediately proceeded the active period of the first component. During these sessions, the completion of the response requirement resulted in the intravenous delivery of saline and the illumination of the conditioned reinforcer over $3 \mathrm{~s}$. Therefore, we subsequently describe these reinstatement tests as drug- and cue-induced reinstatement. We used this combined procedure because it produces pronounced reinstatement of behavior in nonhuman primates (Andersen et al., 2010). To examine the role of 5- $\mathrm{HT} 2_{\mathrm{A}}$ receptors in drug- and cue-induced reinstatement, M100907 (0.3 mg/kg, i.m.) or its vehicle was administered $1 \mathrm{~h}$ before the cocaine prime. The effects of M100907 in this reinstatement were determined across a range of cocaine priming doses $(0.1,0.3$, or $0.56 \mathrm{mg} / \mathrm{kg}$, i.v.), which were administered in a pseudorandomized order.

In vivo microdialysis. Microdialysis samples were collected and analyzed in a manner similar to previously described procedures (Murnane et al., 2010, 2012). Briefly, all procedures were performed in fully conscious subjects while they sat in commercially available primate chairs (Primate Products) within sound-attenuated testing chambers. After the subject was placed in the chamber, $24 \mathrm{~mm}$ (for the caudate) or $28 \mathrm{~mm}$ (for the NAc) stainless steel microdialysis probes with $4 \mathrm{~mm}$ membranes (CMA Microdialysis) were inserted into the subject's surgically implanted guide cannulae. Cocaine was administered through the subcutaneous vascular access port, whereas M100907 was given intramuscularly. Experiments consisted of a $1 \mathrm{~h}$ equilibrium period after which samples were collected every $10 \mathrm{~min}$ for $3.5 \mathrm{~h}$. M100907 was administered intramuscularly $30 \mathrm{~min}$ after the sampling began to provide a baseline period for the assessment of any effects of $5-\mathrm{HT}_{2 \mathrm{~A}}$ receptor antagonism on dopamine levels. As in the behavioral experiments, M100907 $(0.3 \mathrm{mg} / \mathrm{kg}$, i.m.) was administered $60 \mathrm{~min}$ before cocaine administration. Following cocaine administration ( $1.0 \mathrm{mg} / \mathrm{kg}$, i.v.), samples were collected samples over the next $2 \mathrm{~h}$. Adequate probe recovery was verified for each experimental session, both presession and postsession. The viability of the sampling site was verified through retrodialysis of a potassium-enriched (100 $\mathrm{mm}$ ) solution otherwise ionically matched to CSF. Dopamine concentrations within the dialysate were quantified via electrochemical detection using high-pressure liquid chromatography with electrochemical detection, as previously described (Murnane et al., 2010, 2012). The data were analyzed by comparison with standard concentration curves using EZChrom Elite 3.1 (Scientific Software).

Data analysis. In the self-administration and reinstatement studies, the dependent measure was the rate of operant responding (responses per second). The primary dependent variable tested in the microdialysis ex-

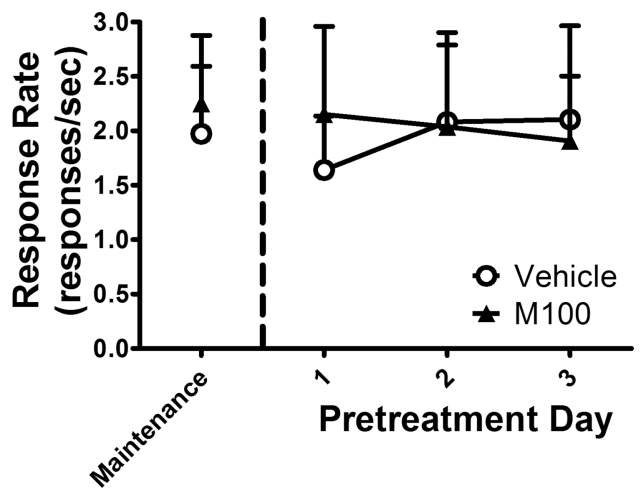

Figure 1. The effects of 3 consecutive days of pretreatment with $M 100907$ (0.3 mg/kg, i.m.) on the self-administration of cocaine at a unit dose of $0.03 \mathrm{mg} / \mathrm{kg} /$ infusion. Open circles represent vehicle pretreatment weeks, and filled triangles represent M100907 pretreatment weeks. All data points $(n=3)$ represent the mean \pm SEM. Abscissae: interval between pretreatments, expressed in days, and plotted on a linear scale. Ordinates: response rate, expressed as responses per second, and plotted on a linear scale.

periments was the extracellular concentration of dopamine in the caudate or NAc. All data were analyzed by two-way repeated-measures (RM) ANOVA, with post hoc comparisons using Dunnett's test or paired $t$ tests. For the behavioral studies, the main factors were pretreatment and either the unit dose of cocaine available for self-administration or the dose of the noncontingent cocaine priming injection. For the microdialysis studies, the three data points immediately preceding the cocaine infusion were averaged to create the baseline. All data points were then normalized as a percentage of this baseline. The main factors in these analyses were time (baseline, 10,20, and 30) and pretreatment. All data points represent the mean \pm the SEM. All graphical data presentations were created by using Prism 4 (GraphPad Software), all statistical tests were performed using SigmaStat 3 (Systat Software), and significance was arbitrated at a probability of $p<0.05$ for all statistical tests.

\section{Results}

\section{Cocaine self-administration}

Under the three-component FR schedule of reinforcement used in this study, the subjects readily exhibited high rates of operant responding, stable performance, and the inverted-U-shaped doseresponse function typical of this procedure (Mello and Negus, 1996). A maximum of 8 infusions per component and 24 infusions per session were available. The subjects typically received $18-22$ infusions at unit doses of cocaine of 0.01 and $0.03 \mathrm{mg} / \mathrm{kg} /$ infusion, and 11-21 infusions at a unit dose of $0.1 \mathrm{mg} / \mathrm{kg} / \mathrm{infu}-$ sion. The dose of cocaine that maintained the highest mean rate of responding was $0.03 \mathrm{mg} / \mathrm{kg} /$ infusion, with rates generally between 1.5 and 2.5 responses/s. Response rates were commonly between 1.4 and 2.1 and 0.4 and 0.8 when unit doses of 0.01 and 0.1 , respectively, were available. The subjects characteristically only responded in the presence of the session light and rapidly completed each ratio following initiation of responding, demonstrating a good schedule control of behavior. As some drugs that target serotonin systems are more effective when given over several days (Davidson et al., 2004), we determined whether subchronic administration of M100907 over 3 d (Wednesday through Friday) engendered more effective suppression of cocaine self-administration than acute administration (Fig. 1). However, there were no significant changes in the effectiveness of M100907 over the $3 \mathrm{~d}$ of treatment that were consistent across the three unit doses of cocaine. A two-way RM ANOVA did reveal the main effects of pretreatment $\left(F_{(1,2)}=26.96, p=0.035\right)$ and day $\left(F_{(3,6)}=6.38, p=0.027\right)$ but no significant interaction $\left(F_{(3,6)}=1.809, p=0.246\right)$ at the lowest dose of cocaine tested. 


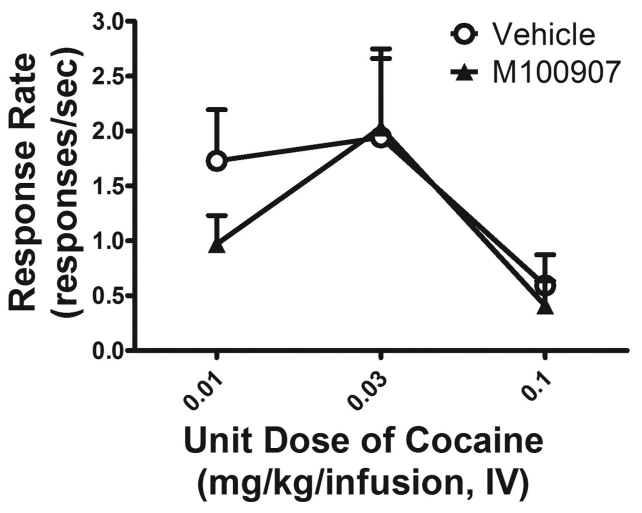

Figure 2. Cocaine self-administration dose-response functions determined from $3 \mathrm{~d}$ averages following pretreatment with M100907 (0.3 mg/kg, i.m.; open circles) or vehicle (filled triangles). All data points ( $n=3$ ) represent the mean \pm SEM Abscissae: unit dose of cocaine available for self-administration, expressed in milligrams per kilogram per infusion, and plotted on a logarithmic scale. Ordinates: response rate, expressed as responses per second, and plotted on a linear scale.

However, subsequent paired $t$ test and one-way RM ANOVA revealed no significant differences between any of the days or pretreatments. Therefore, for the purposes of clarity and simplicity, we averaged the $3 \mathrm{~d}$ of treatment to generate a dose-effect function across all three unit doses of cocaine tested (Fig. 2). Two-way repeated-measures ANOVA revealed no main effects of pretreatment or dose and no significant interaction. Therefore, consistent with previous reports in nonhuman primates and rodents (Fantegrossi et al., 2002; Fletcher et al., 2002; Nic Dhonnchadha et al., 2009), we found little to no effect of antagonizing $5-\mathrm{HT}_{2 \mathrm{~A}}$ receptors on cocaine self-administration, even under conditions optimized to detect these effects.

\section{Reinstatement}

In the reinstatement experiments, ongoing behavior was maintained by the $0.03 \mathrm{mg} / \mathrm{kg} /$ infusion unit dose of cocaine because this dose maintained the highest response rates of any of the three unit doses tested, and the subjects underwent multiple rounds of extinction, reinstatement testing, and re-establishment of stable cocaine self-administration in a pseudo-randomized order. During extinction, response rates typically declined within a couple of sessions from $\sim 2.0$ to $\sim 0.1-0.2$ responses/s. Two-way RM ANOVA revealed a significant main effect of the priming dose $\left(F_{(3,6)}=8.684, p=0.013\right)$ but not pretreatment, and no significant interaction $\left(F_{(3,6)}=2.468, p=0.160\right.$; Fig. 3$)$. A subsequent one-way RM ANOVA $\left(F_{(3,3)}=5.677, p=0.035\right)$ corrected for multiple comparisons using Dunnett's test identified that a priming dose of $0.3 \mathrm{mg} / \mathrm{kg}$ cocaine following vehicle pretreatment significantly reinstated operant behavior compared with extinction $(p<0.05)$. The priming dose of $0.3 \mathrm{mg} / \mathrm{kg}$ engendered response rates of $\sim 0.8$ responses/s, which were $\sim 40 \%$ of the rates typically observed during self-administration of the unit dose of cocaine that maintained the highest rates of behavior. In contrast, following pretreatment with M100907, one-way RM ANOVA revealed no main effect of priming dose $\left(F_{(3,3)}=1.087, p=\right.$ $0.424)$. Consistent with previous studies in rodents (Fletcher et al., 2002; Nic Dhonnchadha et al., 2009), these data show that the $5-\mathrm{HT}_{2 \mathrm{~A}}$ receptors have a more critical role in reinstatement of extinguished behavior previously maintained by cocaine delivery than in the ongoing maintenance of cocaine self-administration.

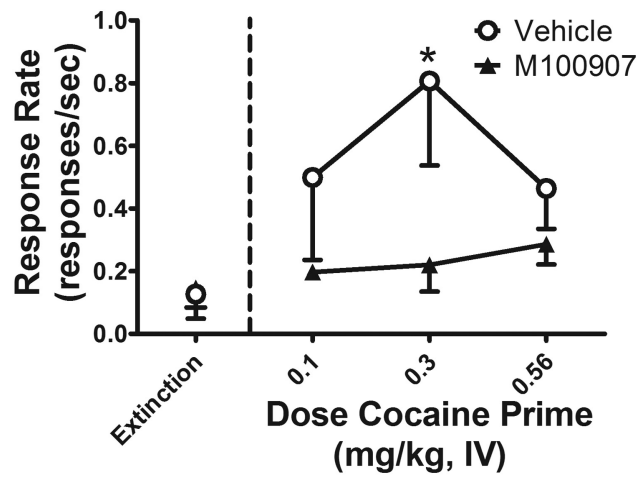

Figure 3. Drug- and cue-induced reinstatement of behavior previously maintained by cocaine delivery following pretreatment with $\mathrm{M} 100907$ (0.3 mg/kg, i.m.; filled triangles) or vehicle (open circles). All data points $(n=3)$ represent the mean \pm SEM. Asterisks $\left(^{*}\right)$ indicate a significant difference $(p<0.05)$ from extinction. Abscissae: dose of the cocaine priming injection noncontingently administered before reinstatement test sessions, expressed in milligrams per kilogram per infusion, and plotted on a logarithmic scale. Ordinates: response rate, expressed as responses per second, and plotted on a linear scale.

\section{In vivo microdialysis}

To elucidate the neuroanatomical and neurochemical basis for the differential role of $5-\mathrm{HT}_{2 \mathrm{~A}}$ receptors in cocaine selfadministration and reinstatement, we examined whether these receptors differentially regulate cocaine-induced overflow through the nigrostriatal and mesolimbic dopamine pathways. Consistent with its lack of influence on cocaine selfadministration, two-way RM ANOVA revealed no main effects of M100907 pretreatment on cocaine-induced dopamine overflow in the NAc (Fig. 4A). This same analysis revealed a main effect of time $\left(F_{(3,9)}=14.150, p<0.001\right)$ and no significant interaction $\left(F_{(3,9)}=0.498, p=0.693\right)$. A subsequent one-way RM ANOVA $\left(F_{(3,3)}=6.321, p=0.014\right)$ corrected for multiple comparisons using Dunnett's post hoc test showed that, following vehicle pretreatment, cocaine significantly elevated extracellular dopamine levels in the NAc at 20 min after injection compared with the baseline $(p<0.05)$, and one-way $\operatorname{RM} \operatorname{ANOVA}\left(F_{(3,3)}=12.794\right.$, $p=0.001)$ showed that, following M100907 pretreatment, cocaine significantly elevated extracellular dopamine levels in the $\mathrm{NAc}$ at 20 and $30 \mathrm{~min}$ after injection compared with the baseline $(p<0.05)$. Furthermore, consistent with its effective attenuation of cocaine- and cue-induced reinstatement, two-way RM ANOVA revealed significant main effects of time $\left(F_{(3,12)}=\right.$ $25.457, p<0.001)$ and pretreatment $\left(F_{(1,4)}=10.741, p=0.031\right)$, and a significant interaction $\left(F_{(3,12)}=9.376, p=0.002\right)$ on cocaine-induced dopamine overflow in the caudate (Fig. 4B). Dunnett's post hoc tests showed that, following vehicle pretreatment, cocaine significantly elevated extracellular dopamine levels in the caudate at 10 and 20 min after injection compared with the baseline $(p<0.05)$, and, following M100907 pretreatment, cocaine significantly elevated extracellular dopamine levels in the caudate at 20 and 30 min after injection compared with the baseline $(p<0.05)$. A paired $t$ test revealed that cocaine was significantly less effective in increasing dopamine overflow in the caudate following M100907 pretreatment than following vehicle pretreatment. It is important to note that cocaine elicited comparable increases in dopamine in the two brain regions after vehicle pretreatment, with levels reaching $1010 \pm 342 \%$ of baseline in the NAc and $840 \pm 58 \%$ of baseline in the caudate. These values are within the range that would be expected under these conditions (Kirkland Henry et al., 2009). The potassium challenge produced a $1020 \pm 396 \%$ change in dopamine levels in the 
A

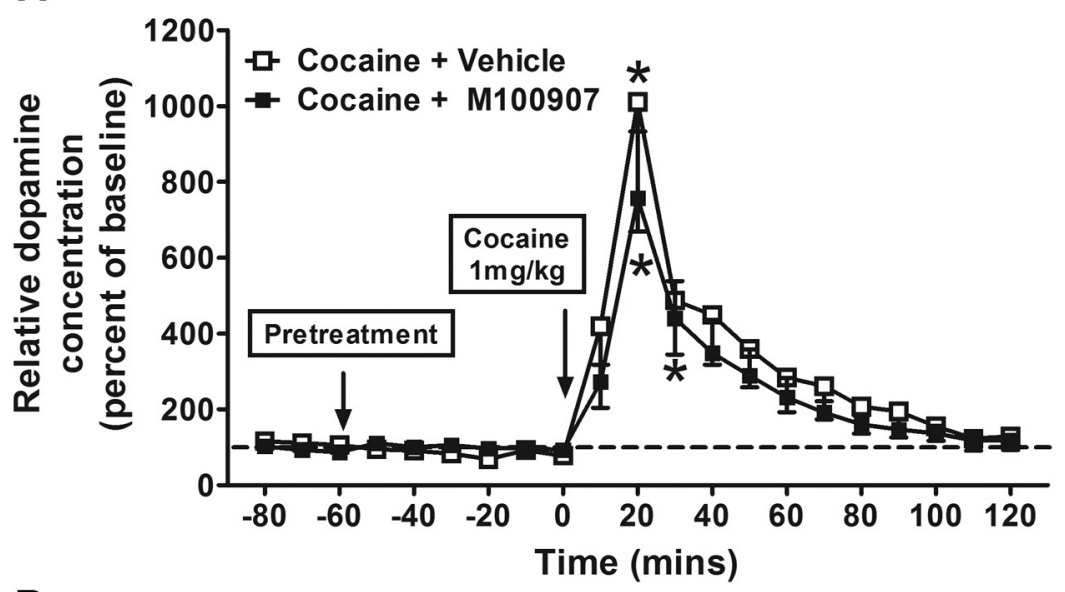

B

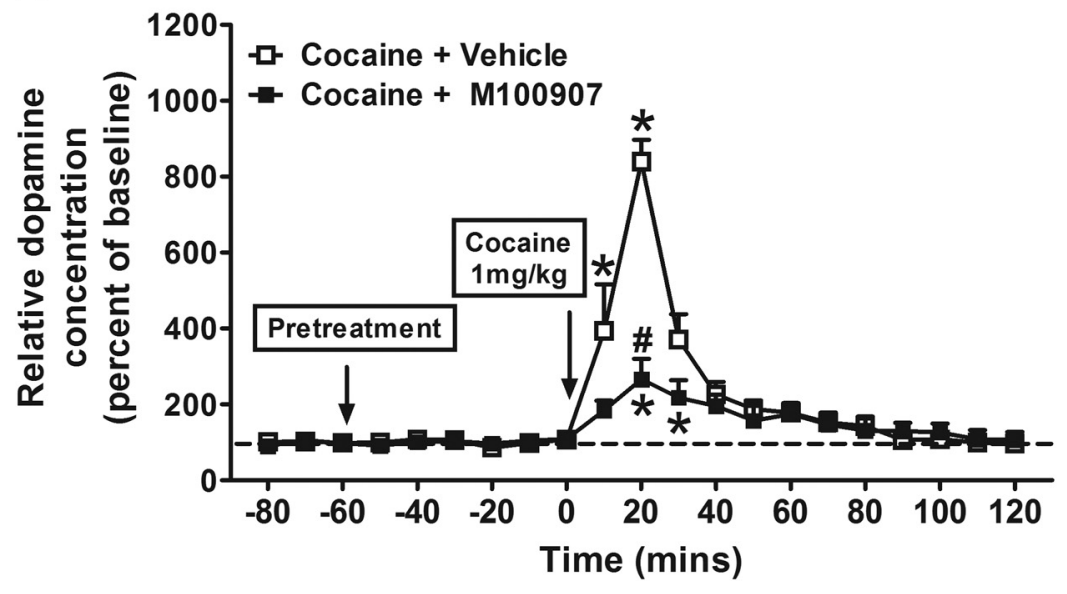

Figure 4. $\quad \boldsymbol{A}, \boldsymbol{B}$, Cocaine-induced increases in extracellular dopamine levels in the nucleus accumbens $(n=4 ; \boldsymbol{A})$ and caudate $(n=5 ; \boldsymbol{B})$ following pretreatment with M100907 (0.3 mg/kg, i.m.; filled triangles and filled squares, respectively) or vehicle (open squares). All data points represent the mean \pm SEM. Pound signs (\#) indicate a significant difference between vehicle and M100907 pretreatments $(p<0.05)$. Asterisks $\left(^{*}\right)$ indicate a significant difference from baseline $(p<0.05)$. Abscissae: time in relation to cocaine injection, expressed in minutes, and plotted on a linear scale. Ordinates: extracellular dopamine concentration, expressed as a percentage of baseline levels, and plotted on a linear scale.

caudate following administration of cocaine plus vehicle and a $716 \pm 248 \%$ change in dopamine levels in the caudate following administration of cocaine plus M100907. The potassium challenge produced a $821 \pm 292 \%$ change in dopamine levels in the NAc following administration of cocaine plus vehicle and a $772 \pm$ $307 \%$ change in dopamine levels in the NAc following administration of cocaine plus M100907.

\section{Discussion}

The major findings of this study are that antagonism of $5-\mathrm{HT}_{2 \mathrm{~A}}$ receptors attenuates reinstatement of extinguished behavior previously maintained by cocaine delivery and attenuates cocaineinduced dopamine overflow in the caudate nucleus. Moreover, in contrast to these effects, antagonism of $5-\mathrm{HT}_{2 \mathrm{~A}}$ receptors does not effectively alter cocaine self-administration or cocaineinduced dopamine overflow in the NAc. Previous studies in rodents have similarly shown insignificant effects of $5-\mathrm{HT}_{2 \mathrm{~A}}$ receptor antagonism by M100907 on cocaine self-administration under a progressive ratio schedule (Fletcher et al., 2002) or an FR schedule (Nic Dhonnchadha et al., 2009) of reinforcement. Likewise, M100907 did not significantly alter rates of cocaine self-administration in rhesus monkeys working under a multi- component FR schedule (Fantegrossi et al., 2002). However, one major difference between the previous rodent and primate studies was the reported baseline rate of behavior. The primates showed one to two orders of magnitude higher rates of behavior, and M100907 produced a trend toward suppression of behavior in these subjects, albeit a nonsignificant trend. Therefore, we designed the current study to include a schedule of reinforcement that would engender high and consistent rates of behavior in well trained subjects, with the expectation that this would provide optimized conditions to detect any effects of M100907. In addition, we determined whether subchronic administration of M100907 would produce any effects on cocaine self-administration. As M100907 had trivial effects on cocaine selfadministration despite these design elements, the consistency of the results among these studies strongly indicates that $5-\mathrm{HT}_{2 \mathrm{~A}}$ receptor antagonism does not alter the reinforcing effects of cocaine.

The present study is the first to report whether $5-\mathrm{HT}_{2 \mathrm{~A}}$ receptor antagonism alters reinstatement of extinguished behavior previously maintained by cocaine delivery in nonhuman primates. In contrast to cocaine self-administration, M100907 effectively attenuated the reinstating effects of a combination of an experimenteradministered priming injection of cocaine and the reintroduction of drug-paired stimuli. This is consistent with rodent studies showing M100907 attenuates the reinstating effects of a cocaine prime (Fletcher et al., 2002) or cocaine-paired cues (Nic Dhonnchadha et al., 2009). These studies strongly support a role for $5-\mathrm{HT}_{2 \mathrm{~A}}$ receptors in the reinstatement of extinguished behavior previously maintained by cocaine delivery. Moreover, insofar as reinstatement is a predictive model of therapeutic effectiveness (Katz and Higgins, 2003), these data further suggest clinical utility for $5-\mathrm{HT}_{2 \mathrm{~A}}$ receptor antagonism in relapse prevention.

The present study is the first to begin to elucidate the neurochemical and neuroanatomical mechanisms by which $5-\mathrm{HT}_{2 \mathrm{~A}}$ receptor antagonism differentially regulates cocaine selfadministration and reinstatement. Using a powerful and directly interpretable microdialysis technique, we found that M100907 attenuated cocaine-induced overflow in the caudate, but not in the NAc. An important limitation of the present study is the lack of ex vivo histological verification of the location of the microdialysis probes within the striatum. It is important to note, however, that we have developed a set of surgical coordinates through a long series of studies that provide highly consistent and accurate targeting of the striatum in primates (Banks et al., 2009; Kimmel et al., 2009; Kirkland Henry et al., 2009; Andersen et al., 2010; Murnane et al., 2010, 2012). Although there is a paucity of data regarding the effects of $5-\mathrm{HT}_{2 \mathrm{~A}}$ receptor antagonism on cocaineinduced dopamine overflow, M100907 attenuates amphetamineinduced dopamine overflow in the caudate in rhesus monkeys 
(Murnane et al., 2013), and the nonselective 5- $\mathrm{HT}_{2 \mathrm{~A} / 2 \mathrm{C}}$ receptor antagonist SR 46349B attenuates amphetamine-induced dopamine overflow in the caudate in rodents (Egerton et al., 2008). As such, there is accumulating evidence that $5-\mathrm{HT}_{2 \mathrm{~A}}$ receptors modulate the nigrostriatal dopamine pathway.

The major dopamine pathways largely arise in the midbrain and project to subcortical and cortical regions. As such, two major points at which $5-\mathrm{HT}_{2 \mathrm{~A}}$ receptors could differentially modulate dopamine overflow through the nigrostriatal and mesolimbic pathways are at the level of the dopamine cell bodies, which send ascending projections to the dorsal and ventral striatum, and at the level of cortical glutamatergic cells that send descending projections back to the striatum and midbrain, which modulate dopamine neurotransmission. A mechanism made appealing by its simplicity is that $5-\mathrm{HT}_{2 \mathrm{~A}}$ receptors are expressed on dopamine cell bodies in the SN but not on those in the VTA. However, this appears not to be the case because direct infusion of M100907 into the VTA attenuates cocaine-induced locomotor activity (McMahon et al., 2001), and 5- $\mathrm{HT}_{2 \mathrm{~A}}$ receptors have been reported on dopamine cells in both the SN and VTA in postmortem human tissue (Ikemoto et al., 2000). Moreover, a long series of studies in the field of psychosis has shown that 5- $\mathrm{HT}_{2 \mathrm{~A}}$ receptors modulate the mesocortical dopamine pathway, which, similar to the mesolimbic pathway, arises in the VTA (Pehek et al., 2001, 2006; Bortolozzi et al., 2005). For example, systemic administration of the preferential $5-\mathrm{HT}_{2 \mathrm{~A}}$ receptor agonist 1-[2,5dimethoxy-4-iodophenyl]-2-aminopropane (DOI) increases the firing rates of VTA dopamine neurons and induces dopamine release in the PFC through a $5-\mathrm{HT}_{2 \mathrm{~A}}$ receptor-dependent mechanism (Bortolozzi et al., 2005; Pehek et al., 2006). It therefore does not appear tenable to suggest that the VTA as a whole is insensitive to modulation by $5-\mathrm{HT}_{2 \mathrm{~A}}$ receptors.

Although some aspects of VTA-mediated activity are sensitive to modulation by $5 \mathrm{HT}_{2 \mathrm{~A}}$ receptors, it is important to recognize that the VTA gives rise to two distinct dopaminergic pathways, namely the mesolimbic and mesocortical pathways. These pathways project from two distinct cellular populations within the VTA, with paranigral dopamine cells giving rise to mesolimbic projections and parabrachial dopamine cells giving rise to mesocortical projections (Lessard et al., 2009). As it is the mesolimbic projections of the VTA that are critical for drug selfadministration, one could speculate that it is the mesolimbic rather than the mesocortical system that is insensitive to modulation by $5-\mathrm{HT}_{2 \mathrm{~A}}$ receptors. Consistent with this contention, $5-\mathrm{HT}_{2 \mathrm{~A}}$ receptor antagonists do not attenuate cocaine selfadministration in rodents or primates (Fantegrossi et al., 2002; Nic Dhonnchadha et al., 2009), and SR 46349B does not attenuate amphetamine-induced dopamine overflow in the NAc in rodents (Auclair et al., 2004; Egerton et al., 2008). Moreover, there are few convincing reports that $5-\mathrm{HT}_{2 \mathrm{~A}}$ receptor agonists are selfadministered by laboratory animals (Siegel and Jarvik, 1980; Fantegrossi et al., 2004). Therefore, it seems reasonable to suggest that the emerging picture is one in which the nigrostriatal and mesocortical dopamine pathways are far more sensitive to modulation by $5-\mathrm{HT}_{2 \mathrm{~A}}$ receptors than the mesolimbic pathway. This may be mediated not by differential expression of $5-\mathrm{HT}_{2 \mathrm{~A}}$ receptors between the SN and VTA but, rather, through differential expression of 5- $\mathrm{HT}_{2 \mathrm{~A}}$ receptors within the VTA itself. Although two previous studies in rodents indicated relatively equal levels of expression of $5-\mathrm{HT}_{2 \mathrm{~A}}$ receptors across the parabrachial and paranigral subnuclei (Doherty and Pickel, 2000; Nocjar et al., 2002), another study showed that paranigral cells were more likely to coexpress both 5- $\mathrm{HT}_{2 \mathrm{~A}}$ and NMDA glutamate receptors (Rodrí- guez et al., 2000). As it is the mesolimbic pathway arising from these paranigral cells that appears to be uniquely insensitive to antagonism of 5-HT2A receptors, perhaps the coexpression of NMDA receptors prevents $5-\mathrm{HT}_{2 \mathrm{~A}}$ receptor antagonists from attenuating paranigral-mediated dopamine overflow in the NAc. To our knowledge, no similar work has been conducted in primates. Given the paucity of data, this hypothesis deserves further study as it could account for the selective insensitivity of the mesolimbic dopamine pathway to $5-\mathrm{HT}_{2 \mathrm{~A}}$ receptors.

An alternative possibility is that $5-\mathrm{HT}_{2 \mathrm{~A}}$ receptors differentially regulate descending cortical glutamatergic projections to nigrostriatal, mesocortical, and mesolimbic dopamine neurons. Consistent with this idea, a recent study reported $\sim 10$-fold higher in vivo availability of $5-\mathrm{HT}_{2 \mathrm{~A}}$ receptors in the $\mathrm{PFC}$ of primates than in the midbrain or striatum (Sawyer et al., 2012). Higher resolution ex vivo approaches showed the highest expression of 5- $\mathrm{HT}_{2 \mathrm{~A}}$ receptors in primates is found in apical dendrites of layer V cortical pyramidal glutamatergic cells of the PFC (Jakab and Goldman-Rakic, 1998), which send both cortical and subcortical projections. Furthermore, these receptors are capable of modulating glutamate neurotransmission as DOI increases glutamate release (Scruggs et al., 2003) through a $5-\mathrm{HT}_{2 \mathrm{~A}}$ receptordependent mechanism (Gewirtz and Marek, 2000; Zhang and Marek, 2008). Moreover, direct PFC projections to the striatum are integrated through a complex striatonigralstriatal system that forms an "ascending spiral" (Haber et al., 2000; Haber and Knutson, 2010). Likewise, a recent study showed that direct infusion of M100907 into the NAc attenuates cocaine-induced dopamine and glutamate overflow in the NAc in cocaine-sensitized subjects (Zayara et al., 2011). As such, there appear to be substantial opportunities for $5-\mathrm{HT}_{2 \mathrm{~A}}$ receptors to regulate efferent glutamatergic modulation of specific dopaminergic systems.

Evidence has accumulated from a variety of sources that there is a critical role for descending glutamate projections in drug- and cue-induced reinstatement, and these projections are driven by dopamine release via the mesocortical pathways into the PFC (McFarland et al., 2003; Kalivas, 2007, 2009). Accordingly, it is possible that $5-\mathrm{HT}_{2 \mathrm{~A}}$ receptor antagonism attenuates reinstatement of extinguished behavior previously maintained by cocaine delivery by reducing mesocortical dopamine drive onto the PFC through receptors expressed on parabrachial VTA neurons, and attenuating glutamatergic output from the PFC though inhibition of layer V pyramidal cells. Moreover, it is likely that this cortical glutamatergic output more strongly regulates reinstatement than maintenance of ongoing self-administration (Kalivas, 2009). In primates, we have consistently shown using PET imaging and functional MRI that noncontingent infusions of cocaine activate the PFC (Howell et al., 2002, 2010; Henry et al., 2010; Murnane and Howell, 2010), and we have recently reported that the response of these areas changes following exposure to cocaine (Henry et al., 2010). In future studies, we will continue to explore this circuitry using behavior, neurochemical, and neuroimaging approaches, and, particularly, functional connectivity between the PFC and striatum, as this will allow for the further elucidation of neurobiological circuits relevant for cocaine abuse and relapse, and the development of biomarkers for successful treatment responses.

\section{References}

Andersen ML, Kessler E, Murnane KS, McClung JC, Tufik S, Howell LL (2010) Dopamine transporter-related effects of modafinil in rhesus monkeys. Psychopharmacology (Berl) 210:439-448. CrossRef Medline Auclair A, Blanc G, Glowinski J, Tassin JP (2004) Role of serotonin 2A re- 
ceptors in the $\mathrm{D}$-amphetamine-induced release of dopamine: comparison with previous data on alphalb-adrenergic receptors. J Neurochem 91: 318-326. CrossRef Medline

Banks ML, Andersen ML, Murnane KS, Meyer RC, Howell LL (2009) Behavioral and neurochemical effects of cocaine and diphenhydramine combinations in rhesus monkeys. Psychopharmacology (Berl) 205:467-474. CrossRef Medline

Belin D, Everitt BJ (2008) Cocaine seeking habits depend upon dopaminedependent serial connectivity linking the ventral with the dorsal striatum. Neuron 57:432-441. CrossRef Medline

Bortolozzi A, Díaz-Mataix L, Scorza MC, Celada P, Artigas F (2005) The activation of 5-HT receptors in prefrontal cortex enhances dopaminergic activity. J Neurochem 95:1597-1607. CrossRef Medline

Davidson C, Lazarus C, Lee TH, Ellinwood EH (2004) Ondansetron, given during the acute cocaine withdrawal, attenuates oral cocaine selfadministration. Eur J Pharmacol 503:99-102. CrossRef Medline

Doherty MD, Pickel VM (2000) Ultrastructural localization of the serotonin $2 \mathrm{~A}$ receptor in dopaminergic neurons in the ventral tegmental area. Brain Res 864:176-185. CrossRef Medline

Egerton A, Ahmad R, Hirani E, Grasby PM (2008) Modulation of striatal dopamine release by 5-HT2A and 5-HT2C receptor antagonists: [11C]raclopride PET studies in the rat. Psychopharmacology (Berl) 200:487-496. CrossRef Medline

Fantegrossi WE, Ullrich T, Rice KC, Woods JH, Winger G (2002) 3,4Methylenedioxymethamphetamine (MDMA, "ecstasy") and its stereoisomers as reinforcers in rhesus monkeys: serotonergic involvement. Psychopharmacology (Berl) 161:356-364. CrossRef Medline

Fantegrossi WE, Woods JH, Winger G (2004) Transient reinforcing effects of phenylisopropylamine and indolealkylamine hallucinogens in rhesus monkeys. Behav Pharmacol 15:149-157. CrossRef Medline

Fantegrossi WE, Bauzo RM, Manvich DM, Morales JC, Votaw JR, Goodman MM, Howell LL (2009) Role of dopamine transporters in the behavioral effects of 3,4-methylenedioxymethamphetamine (MDMA) in nonhuman primates. Psychopharmacology (Berl) 205:337-347. CrossRef Medline

Fletcher PJ, Grottick AJ, Higgins GA (2002) Differential effects of the 5-HT(2A) receptor antagonist M100907 and the 5-HT(2C) receptor antagonist SB242084 on cocaine-induced locomotor activity, cocaine selfadministration and cocaine-induced reinstatement of responding. Neuropsychopharmacology 27:576-586. CrossRef Medline

Gewirtz JC, Marek GJ (2000) Behavioral evidence for interactions between a hallucinogenic drug and group II metabotropic glutamate receptors. Neuropsychopharmacology 23:569-576. CrossRef Medline

Haber SN, Knutson B (2010) The reward circuit: linking primate anatomy and human imaging. Neuropsychopharmacology 35:4-26. CrossRef Medline

Haber SN, Fudge JL, McFarland NR (2000) Striatonigrostriatal pathways in primates form an ascending spiral from the shell to the dorsolateral striatum. J Neurosci 20:2369-2382. Medline

Haber SN, Kim KS, Mailly P, Calzavara R (2006) Reward-related cortical inputs define a large striatal region in primates that interface with associative cortical connections, providing a substrate for incentive-based learning. J Neurosci 26:8368-8376. CrossRef Medline

Henry PK, Murnane KS, Votaw JR, Howell LL (2010) Acute brain metabolic effects of cocaine in rhesus monkeys with a history of cocaine use. Brain Imaging Behav 4:212-219. CrossRef Medline

Howell LL, Murnane KS (2008) Nonhuman primate neuroimaging and the neurobiology of psychostimulant addiction. Ann N Y Acad Sci 1141:176-194. CrossRef Medline

Howell LL, Hoffman JM, Votaw JR, Landrum AM, Wilcox KM, Lindsey KP (2002) Cocaine-induced brain activation determined by positron emission tomography neuroimaging in conscious rhesus monkeys. Psychopharmacology (Berl) 159:154-160. CrossRef Medline

Howell LL, Votaw JR, Goodman MM, Lindsey KP (2010) Cortical activation during cocaine use and extinction in rhesus monkeys. Psychopharmacology (Berl) 208:191-199. CrossRef Medline

Ikemoto K, Nishimura A, Okado N, Mikuni M, Nishi K, Nagatsu I (2000) Human midbrain dopamine neurons express serotonin 2A receptor: an immunohistochemical demonstration. Brain Res 853:377-380. CrossRef Medline

Ito R, Dalley JW, Robbins TW, Everitt BJ (2002) Dopamine release in the dorsal striatum during cocaine-seeking behavior under the control of a drug-associated cue. J Neurosci 22:6247-6253. Medline
Jakab RL, Goldman-Rakic PS (1998) 5-Hydroxytryptamine2A serotonin receptors in the primate cerebral cortex: possible site of action of hallucinogenic and antipsychotic drugs in pyramidal cell apical dendrites. Proc Natl Acad Sci U S A 95:735-740. CrossRef Medline

Johnston LD, O’Malley PM, Bachman JG, Schulenberg JE (2011) Monitoring the Future national survey results on drug use, 1975-2010, Vol I: secondary school students. Ann Arbor, MI: Institute for Social Research, The University of Michigan.

Kalivas PW (2007) Cocaine and amphetamine-like psychostimulants: neurocircuitry and glutamate neuroplasticity. Dialogues Clin Neurosci 9:389-397. Medline

Kalivas PW (2009) The glutamate homeostasis hypothesis of addiction. Nat Rev Neurosci 10:561-572. CrossRef Medline

Katz JL, Higgins ST (2003) The validity of the reinstatement model of craving and relapse to drug use. Psychopharmacology (Berl) 168:21-30. CrossRef Medline

Kimmel HL, Manvich DF, Blough BE, Negus SS, Howell LL (2009) Behavioral and neurochemical effects of amphetamine analogs that release monoamines in the squirrel monkey. Pharmacol Biochem Behav 94:278-284. CrossRef Medline

Kirkland Henry P, Davis M, Howell LL (2009) Effects of cocaine selfadministration history under limited and extended access conditions on in vivo striatal dopamine neurochemistry and acoustic startle in rhesus monkeys. Psychopharmacology (Berl) 205:237-247. CrossRef Medline

Lessard A, Savard M, Gobeil F Jr, Pierce JP, Pickel VM (2009) The neurokinin-3 (NK3) and the neurokinin-1 (NK1) receptors are differentially targeted to mesocortical and mesolimbic projection neurons and to neuronal nuclei in the rat ventral tegmental area. Synapse 63:484-501. CrossRef Medline

McFarland K, Lapish CC, Kalivas PW (2003) Prefrontal glutamate release into the core of the nucleus accumbens mediates cocaine-induced reinstatement of drug-seeking behavior. J Neurosci 23:3531-3537.

McMahon LR, Filip M, Cunningham KA (2001) Differential regulation of the mesoaccumbens circuit by serotonin 5-hydroxytryptamine (5-HT)2A and 5-HT2C receptors. J Neurosci 21:7781-7787.

Mello NK, Negus SS (1996) Preclinical evaluation of pharmacotherapies for treatment of cocaine and opioid abuse using drug self-administration procedures. Neuropsychopharmacology 14:375-424. CrossRef Medline

Murnane KS, Howell LL (2010) Development of an apparatus and methodology for conducting functional magnetic resonance imaging (fMRI) with pharmacological stimuli in conscious rhesus monkeys. J Neurosci Methods 191:11-20. CrossRef Medline

Murnane KS, Fantegrossi WE, Godfrey JR, Banks ML, Howell LL (2010) Endocrine and neurochemical effects of 3,4-methylenedioxymethamphetamine and its stereoisomers in rhesus monkeys. J Pharmacol Exp Ther 334:642-650. CrossRef Medline

Murnane KS, Kimmel HL, Rice KC, Howell LL (2012) The neuropharmacology of prolactin secretion elicited by 3,4-methylenedioxymethamphetamine ("ecstasy"): a concurrent microdialysis and plasma analysis study. Horm Behav 61:181-190. CrossRef Medline

Murnane KS, Andersen ML, Rice KC, Howell LL (2013) Selective serotonin $2 \mathrm{~A}$ receptor antagonism attenuates the effects of amphetamine on arousal and dopamine overflow in non-human primates. J Sleep Res, in press. CrossRef

Nic Dhonnchadha BA, Fox RG, Stutz SJ, Rice KC, Cunningham KA (2009) Blockade of the serotonin 5-HT2A receptor suppresses cue-evoked reinstatement of cocaine-seeking behavior in a rat self-administration model. Behav Neurosci 123:382-396. CrossRef Medline

Nocjar C, Roth BL, Pehek EA (2002) Localization of 5-HT(2A) receptors on dopamine cells in subnuclei of the midbrain A10 cell group. Neuroscience 111:163-176. CrossRef Medline

O’Brien CP, Gardner EL (2005) Critical assessment of how to study addiction and its treatment: human and nonhuman animal models. Pharmacol Ther 108:18-58. CrossRef Medline

Pehek EA, McFarlane HG, Maguschak K, Price B, Pluto CP (2001) M100,907, a selective 5-HT(2A) antagonist, attenuates dopamine release in the rat medial prefrontal cortex. Brain Res 888:51-59. CrossRef Medline

Pehek EA, Nocjar C, Roth BL, Byrd TA, Mabrouk OS (2006) Evidence for the preferential involvement of 5-HT2A serotonin receptors in stress- and drug-induced dopamine release in the rat medial prefrontal cortex. Neuropsychopharmacology 31:265-277. CrossRef Medline 
Porrino LJ, Smith HR, Nader MA, Beveridge TJ (2007) The effects of cocaine: a shifting target over the course of addiction. Prog Neuropsychopharmacol Biol Psychiatry 31:1593-1600. CrossRef Medline

Rodríguez JJ, Doherty MD, Pickel VM (2000) N-methyl-D-aspartate (NMDA) receptors in the ventral tegmental area: subcellular distribution and colocalization with 5-hydroxytryptamine(2A) receptors. J Neurosci Res 60:202-211. CrossRef Medline

Sawyer EK, Mun J, Nye JA, Kimmel HL, Voll RJ, Stehouwer JS, Rice KC, Goodman MM, Howell LL (2012) Neurobiological changes mediating the effects of chronic fluoxetine on cocaine use. Neuropsychopharmacology 37:1816-1824. CrossRef Medline

Scruggs JL, Schmidt D, Deutch AY (2003) The hallucinogen 1-[2,5dimethoxy-4-iodophenyl]-2-aminopropane (DOI) increases cortical extracellular glutamate levels in rats. Neurosci Lett 346:137-140. CrossRef Medline

Siegel RK, Jarvik ME (1980) DMT self-administration by monkey in isolation. Bull Psychon Soc 16:117-120.

Stewart J, de Wit H (1987) Reinstatement of drug-taking behavior as a method of assessing incentive motivational properties of drugs. In: Methods of assessing the reinforcing properties of abused drugs (Bozarth MA, ed), pp 211-227. New York: Springer.
Wilcox KM, Lindsey KP, Votaw JR, Goodman MM, Martarello L, Carroll FI, Howell LL (2002) Self-administration of cocaine and the cocaine analog RTI-113: relationship to dopamine transporter occupancy determined by PET neuroimaging in rhesus monkeys. Synapse 43:7885. CrossRef Medline

Wilcox KM, Kimmel HL, Lindsey KP, Votaw JR, Goodman MM, Howell LL (2005) In vivo comparison of the reinforcing and dopamine transporter effects of local anesthetics in rhesus monkeys. Synapse 58:220-228. CrossRef Medline

Zayara AE, McIver G, Valdivia PN, Lominac KD, McCreary AC, Szumlinski KK (2011) Blockade of nucleus accumbens 5-HT2A and 5-HT2C receptors prevents the expression of cocaine-induced behavioral and neurochemical sensitization in rats. Psychopharmacology (Berl) 213: 321-335. CrossRef Medline

Zhang C, Marek GJ (2008) AMPA receptor involvement in 5hydroxytryptamine $2 \mathrm{~A}$ receptor-mediated prefrontal cortical excitatory synaptic currents and DOI-induced head shakes. Prog Neuropsychopharmacol Biol Psychiatry 32:62-71. CrossRef Medline 